\title{
\#USES
}

science for a changing world

Groundwater Resources Program

Annual and Average Estimates of Water-Budget

Components Based on Hydrograph Separation and PRISM Precipitation for Gaged Basins in the Appalachian Plateaus Region, 1900-2011

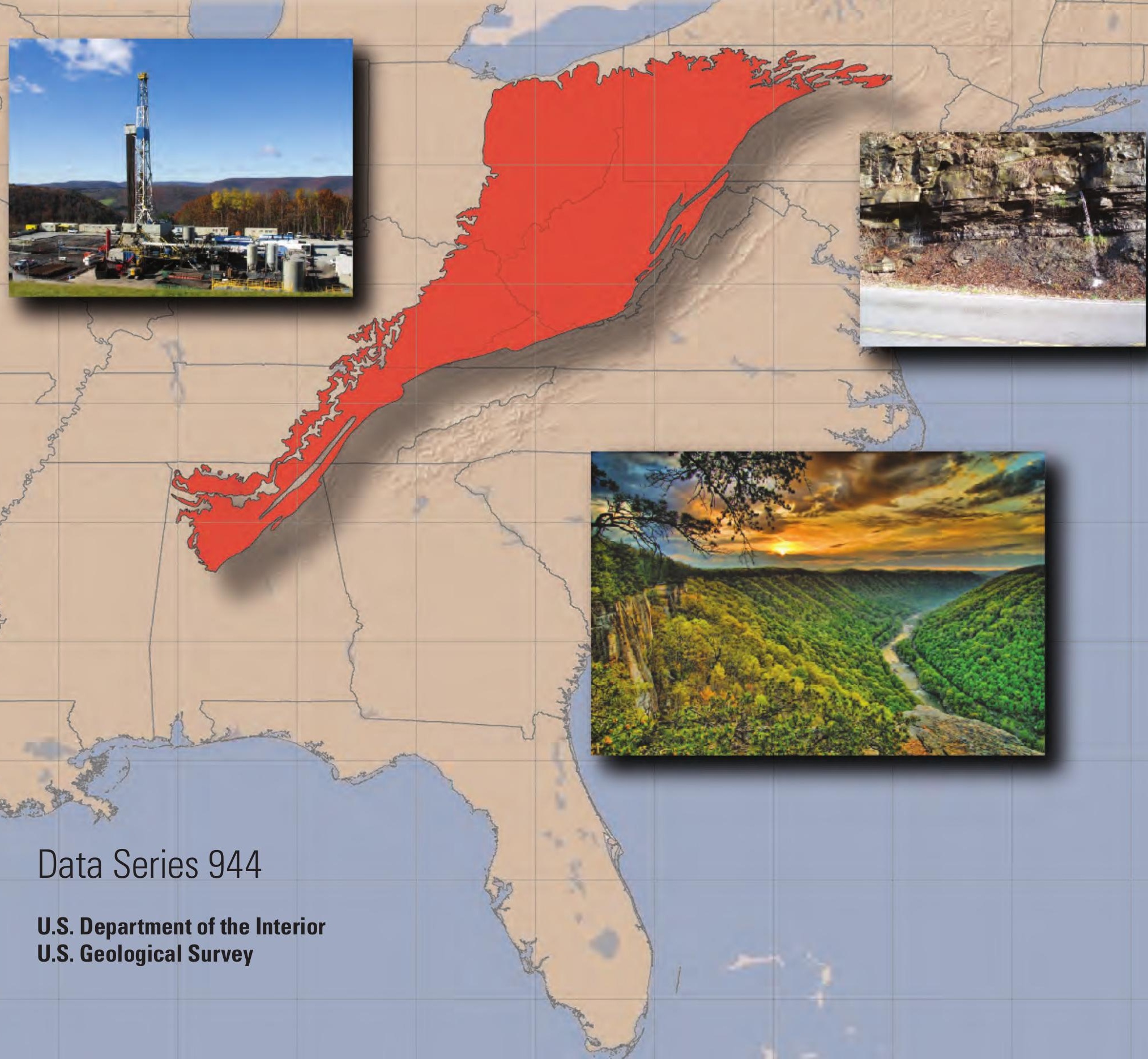


Cover. Left, Drilling of Marcellus Shale well by Seneca Resources in Pennsylvania (photograph courtesy of Matthew Henderson, Penn State Marcellus Center for Outreach and Research; right top, Groundwater discharge from fractured rock in West Virginia (photograph courtesy of Mark Kozar, U.S. Geological Survey); right bottom, Sunrise over the Endless Wall from Diamond Point, New River Gorge National River (photograph courtesy of Gary Hartley, National Park Service). 


\section{Annual and Average Estimates of Water-Budget Components Based on Hydrograph Separation and PRISM Precipitation for Gaged Basins in the Appalachian Plateaus Region, 1900-2011}

By David L. Nelms, Terence Messinger, and Kurt J. McCoy

Groundwater Resources Program

Data Series 944 


\title{
U.S. Department of the Interior SALLY JEWELL, Secretary
}

\section{U.S. Geological Survey Suzette M. Kimball, Acting Director}

\author{
U.S. Geological Survey, Reston, Virginia: 2015
}

For more information on the USGS - the Federal source for science about the Earth, its natural and living resources, natural hazards, and the environment-visit http://www.usgs.gov or call 1-888-ASK-USGS.

For an overview of USGS information products, including maps, imagery, and publications, visit http://www.usgs.gov/pubprod/.

Any use of trade, firm, or product names is for descriptive purposes only and does not imply endorsement by the U.S. Government.

Although this information product, for the most part, is in the public domain, it also may contain copyrighted materials as noted in the text. Permission to reproduce copyrighted items must be secured from the copyright owner.

Suggested citation:

Nelms, D.L., Messinger, Terence, and McCoy, K.J., 2015, Annual and average estimates of water-budget components based on hydrograph separation and PRISM precipitation for gaged basins in the Appalachian Plateaus Region, 1900-2011: U.S. Geological Survey Data Series 944, 10 p., http://dx.doi.org/10.3133/ds944. 


\section{Contents}

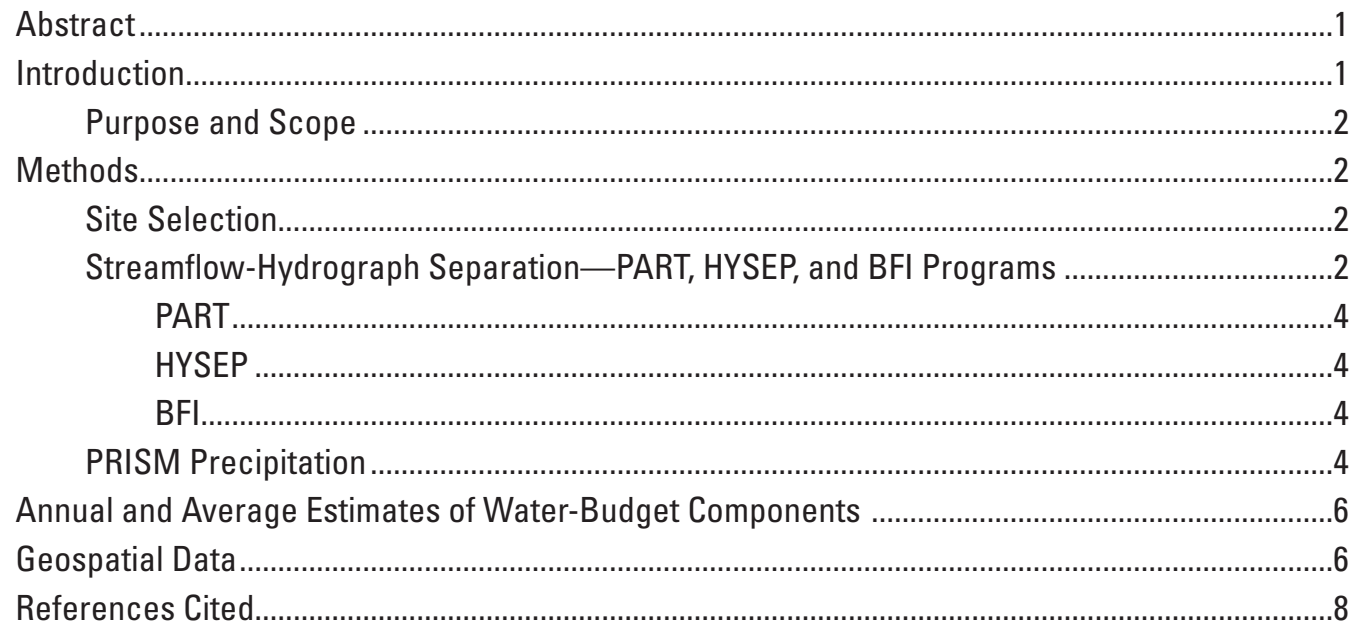

\section{Oversize Items}

[Microsoft Excel files available for download at http://pubs.usgs.gov/ds/0944/]

Appendix 1. List of streamflow-gaging stations in the Appalachian Plateaus region used to estimate annual water-budget components based on hydrograph separation and PRISM precipitation, 1900-2011

Appendix 2. Annual estimates of water-budget components based on hydrograph separation and PRISM precipitation for gaged basins in the Appalachian Plateaus region, 1900-2011

Appendix 3. Average estimates for the period of analysis of water-budget components based on hydrograph separation and PRISM precipitation for gaged basins in the Appalachian Plateaus region, 1900-2011

\section{Figures}

1. Map showing location of streamflow-gaging stations used for hydrograph separation in the Appalachian Plateaus region.

2. Hydrograph showing the results of streamflow partitioning from PART at streamflow-gaging station 03208500 Russell Fork at Haysi, Virginia

3. Hydrographs showing the results from the HYSEP program - the fixed interval, sliding interval, and local minimum methods - at streamflow-gaging station 03208500 Russell Fork at Haysi, Virginia

4. Hydrographs showing the results from the BFI program - the standard and modified approaches-at streamflow-gaging station 03208500 Russell Fork at Haysi, Virginia ....

5. Graph showing relation between average base-flow values estimated from the PART method and drainage area of streamflow-gaging stations in the Appalachian Plateaus region 


\section{Conversion Factors}

Inch/Pound to SI

\begin{tabular}{lcl}
\hline \multicolumn{1}{c}{ Multiply } & By & \multicolumn{1}{c}{ To obtain } \\
\hline inch (in.) & Length & \\
inch (in.) & 2.54 & centimeter $(\mathrm{cm})$ \\
& 25.4 & millimeter $(\mathrm{mm})$ \\
\hline square mile $\left(\mathrm{mi}^{2}\right)$ & Area & hectare $(\mathrm{ha})$ \\
square mile $\left(\mathrm{mi}^{2}\right)$ & 259.0 & square kilometer $\left(\mathrm{km}^{2}\right)$ \\
\hline & 2.590 & \\
\hline cubic foot per second $\left(\mathrm{ft}^{3} / \mathrm{s}\right)$ & Flow rate & cubic meter per second $\left(\mathrm{m}^{3} / \mathrm{s}\right)$ \\
inch per year $(\mathrm{in} / \mathrm{yr})$ & 0.02832 & millimeter per year $(\mathrm{mm} / \mathrm{yr})$ \\
\hline
\end{tabular}

\section{Datum}

Horizontal coordinate information is referenced to the North American Datum of 1983 (NAD 83).

\section{Abbreviations}

$\mathrm{BFI}$

base-flow index

DEM

digital elevation model

ET

evapotranspiration

FGDC

Federal Geographic Data Committee

GW

Groundwater (Toolbox)

NSDI

National Spatial Data Inventory

PRISM

parameter-elevation regressions on independent slopes model

STAID

station identification number

USGS

U.S. Geological Survey 


\title{
Annual and Average Estimates of Water-Budget Components Based on Hydrograph Separation and PRISM Precipitation for Gaged Basins in the Appalachian Plateaus Region, 1900-2011
}

\author{
By David L. Nelms, Terence Messinger, and Kurt J. McCoy
}

\section{Abstract}

As part of the U.S. Geological Survey's Groundwater Resources Program study of the Appalachian Plateaus aquifers, annual and average estimates of water-budget components based on hydrograph separation and precipitation data from parameter-elevation regressions on independent slopes model (PRISM) were determined at 849 continuous-record streamflow-gaging stations from Mississippi to New York and covered the period of 1900 to 2011. Only complete calendar years (January to December) of streamflow record at each gage were used to determine estimates of base flow, which is that part of streamflow attributed to groundwater discharge; such estimates can serve as a proxy for annual recharge. For each year, estimates of annual base flow, runoff, and base-flow index were determined using computer programs-PART, HYSEP, and $\mathrm{BFI}$ - that have automated the separation procedures. These streamflow-hydrograph analysis methods are provided with version 1.0 of the U.S. Geological Survey Groundwater Toolbox, which is a new program that provides graphing, mapping, and analysis capabilities in a Windows environment. Annual values of precipitation were estimated by calculating the average of cell values intercepted by basin boundaries where previously defined in the GAGES-II dataset. Estimates of annual evapotranspiration were then calculated from the difference between precipitation and streamflow.

\section{Introduction}

Annual and average estimates of water-budget components based on hydrograph separation and precipitation data from parameter-elevation regressions on independent slopes model (PRISM) were determined at 849 continuous record streamflow-gaging stations from Mississippi to New York. These estimates were made as part of the U.S. Geological Survey (USGS) Groundwater Resources Program study of the Appalachian Plateaus aquifers, and cover the period from 1900 to 2011. Only complete calendar years (January to December) of streamflow record at each gage were used to determine estimates of base flow.

Risser and others (2005) state that base flow is not equivalent to recharge, but it is often used as a proxy for recharge when underflow, evapotranspiration from riparian vegetation, and other losses of groundwater from the watershed are assumed to be minimal. Base flow is the groundwater discharge component of streamflow (U.S. Geological Survey, 1989). Two fundamental assumptions are that base flow equals groundwater discharge and that groundwater discharge approximately equals groundwater recharge when compiled over a long period of time (1 year or more) (Trainer and Watkins, 1975; Richardson, 1982; Risser and others, 2005). The base-flow estimates provided in this report do not represent total recharge to the aquifers and are often referred to as "effective recharge" (Daniel, 1996; Rutledge and Mesko, 1996; Nelms and others, 1997), "base recharge" (Szilagyi and others, 2003), or "observable recharge" (Holtschlag, 1997). Because the hydrograph-separation techniques can produce different estimates for a given area and time period, Risser and others (2005) note that users should determine which estimate, if any, best represents recharge in their particular watershed or area. Rutledge (1998) adds that because of climatic variation, comparisons between basins should only be made for uniform time periods. 


\section{Purpose and Scope}

This report presents annual and average estimates of water-budget components based on three hydrograph separation techniques-PART (Rutledge, 1993), HYSEP (Sloto and Crouse, 1996), and BFI (Wahl and Wahl, 1988) — and precipitation data from PRISM at 849 continuous-record streamflow-gaging stations within the Appalachian Plateaus region, which extends from Mississippi to New York and includes the surface-water basins that drain within or into areas underlain by Appalachian Plateaus aquifers. Estimates of runoff are provided by subtracting the base-flow estimates from streamflow. Estimates of the base-flow index (BFI), which is the percentage of streamflow from base flow, are also presented. For those basins whose boundaries were previously defined in the GAGES-II dataset (Falcone, 2011), annual estimates of evapotranspiration (ET) are presented and were calculated by subtracting annual streamflow from the annual precipitation computed for each basin.

Three appendixes are included as Microsoft Excel spreadsheets that present (1) site and locational information for the 849 streamflow-gaging stations within the Appalachian Plateaus Region where hydrograph separation was conducted, (2) annual estimates from each separation technique, and (3) average values of water-budget components for the period of analysis at each streamflow-gaging station. The three separation techniques provide a set of six estimates of base flow, runoff, and BFI for each year of complete record, for a total of 20,990 annual sets. Geospatial data identical to those provided in appendixes 1-3 are contained in a personal geodatabase available at the USGS Water Resources National Spatial Data Inventory (NSDI) Node.

\section{Methods}

The U.S. Geological Survey's Groundwater (GW) Toolbox, version 1 (Barlow and others, 2015), which is a new program that provides graphing, mapping, and analysis capabilities in a Windows environment, was used to select sites, download streamflow data, and follow the different hydrograph separation methods for the individual streamflowgaging stations having continuous mean daily streamflow records within the Appalachian Plateaus region. Descriptions of site-selection criteria and the individual hydrograph separation methods utilized by GW Toolbox are provided next.

\section{Site Selection}

Streamflow gaging stations were selected for hydrograph separation analysis based on location, drainage area size, complete years of streamflow record, and streamflow regulation status. An initial set of continuous streamflow-gaging stations within the Appalachian Plateaus region was compiled. In order to meet the hydrograph separation requirement that antecedent recession exceeds the time increment of the data (1 day), only gages associated with drainage areas larger than 1 square mile $\left(\mathrm{mi}^{2}\right)$ were selected from the initial compilation. The upper limit of drainage area size is somewhat ambiguous and dependent upon the degree of nonuniformity of weather systems (Rutledge, 1998). For this study, the authors selected an upper limit of $500 \mathrm{mi}^{2}$ for drainage area size, which follows the recommendation established by Rutledge (1998). For this study, hydrograph separation methods were applied to those sites having at least 1 year of complete streamflow record from January through December; however, recharge estimates for sites having less than 10 years of complete record may be erroneous because of limited temporal climatic variation, and estimates for such sites having drainage areas less than $10 \mathrm{mi}^{2}$ also may be subject to the influence of localized spatial variability in precipitation. Streamflow regulation can impact base-flow estimates and was considered as part of the site selection process. For unregulated sites and sites having known periods of regulated flow, only complete years of known unregulated flow were considered. If the period of regulation was unknown but data from the gage was used in previous USGS reports containing low-flow statistics or stream characteristics, then hydrograph separation was conducted for the entire period of record.

The 849 continuous-record streamflow-gaging stations shown in figure 1 met all of the selection criteria. Gages having 60 or more years of complete record between the years 1930 and 2011, no more than 20 percent missing data, and previously defined basin boundaries in the GAGES-II dataset (Falcone, 2011) are referred to as "index gages" and are indicated in figure 1. The complete list of the 849 streamflowgaging stations in the Appalachian Plateaus region where annual values for base flow were estimated is provided in appendix 1.

\section{Streamflow-Hydrograph Separation-PART, HYSEP, and BFI Programs}

Several automated computer programs are available for hydrograph separation and estimation of groundwater recharge (Pettyjohn and Henning, 1979; Wahl and Wahl, 1988; Nathan and McMahon, 1990; Rutledge, 1993; Arnold and others, 1995; Sloto and Crouse, 1996), four of these methods have been incorporated as a suite of hydrologic application tools within the U.S. Geological Survey's GW Toolbox-PART, HYSEP, BFI, and RORA (Barlow and others, 2015). PART (Rutledge, 1993, 1998) and HYSEP (Sloto and Crouse, 1996) use somewhat arbitrary, but different, criteria to separate or "scalp" base flow from a streamflow hydrograph (Risser and others, 2005). BFI (Wahl and Wahl, 1988) is a deterministic procedure originally proposed in 1980 by the British Institute of Hydrology (Institute of Hydrology, 1980a, b). RORA (Rutledge, 1993, 1998), which is included in the GW Toolbox but was not applied in this study, is a single recession-curve displacement method used to calculate groundwater recharge that requires evaluation of multiple recession events over time. 


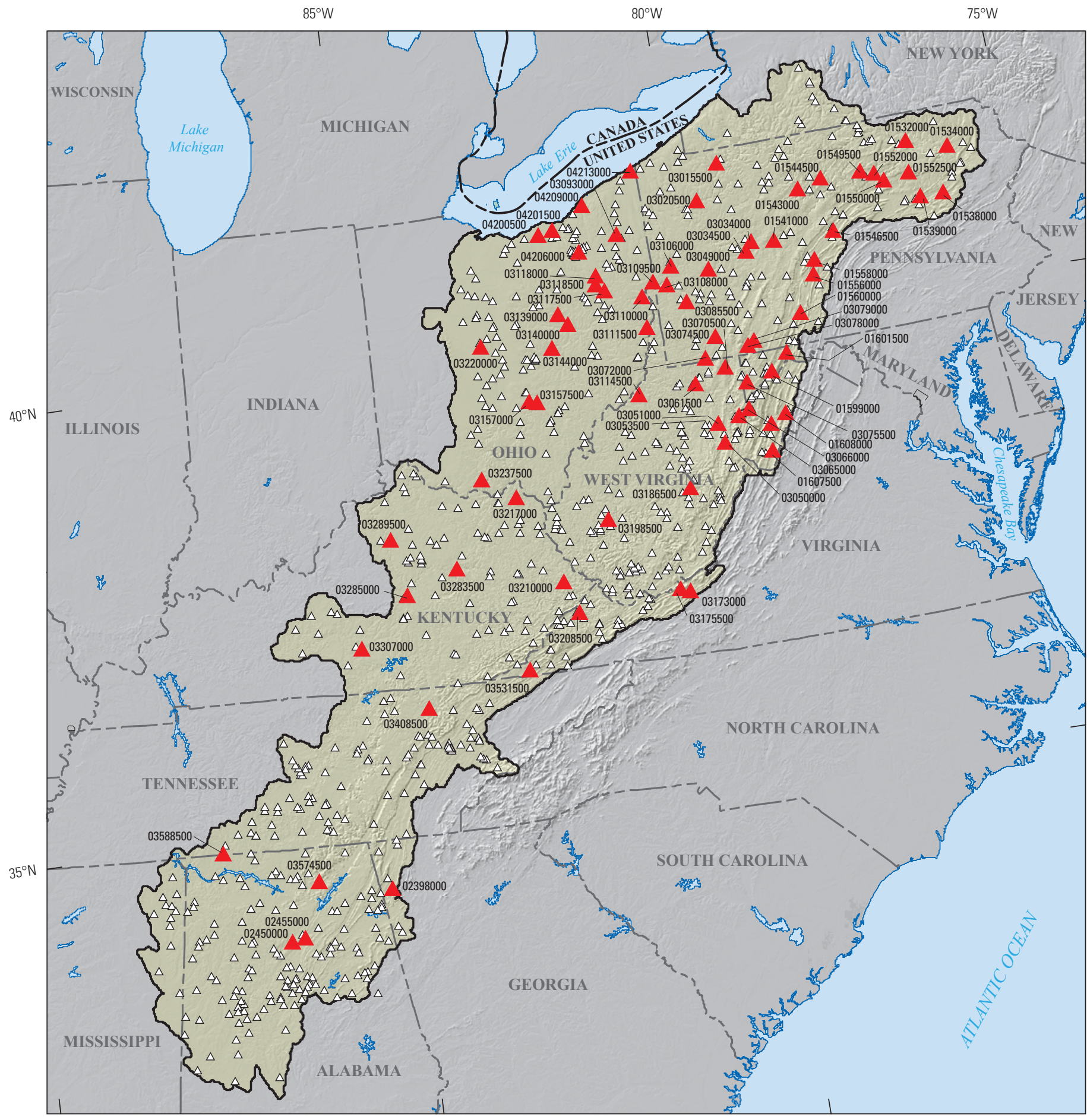

Base from Esri Data \& Maps, 2008 Esri World Shaded Relief, 2014

Albers Equal-Area Conic projection Standard parallels $29^{\circ} 30^{\prime}$ and $45^{\circ} 30^{\prime}$ Central meridian $96^{\circ}$

North American Datum of 1983

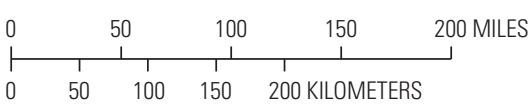

EXPLANATION

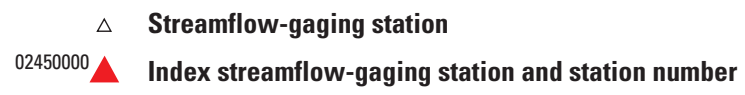

Figure 1. Location of streamflow-gaging stations used for hydrograph separation in the Appalachian Plateaus region. Index gages were defined as having 60 or more years of complete record between the years 1930 and 2011, no more than 20 percent missing data, and previously defined basin boundaries in the GAGES-II dataset (Falcone, 2011). 


\section{PART}

PART estimates a daily record of base flow as a component of the streamflow record by using a form of streamflow partitioning that is based on antecedent streamflow recession (Rutledge, 1998). Base flow is set to equal streamflow on days that are unaffected by surface runoff or interflow (stormflow) and then is determined by linear interpolation between these days for the remainder of the hydrograph for the period analyzed (fig. 2). Base flow is equivalent to streamflow when the antecedent-recession length is greater than $N$ and the rate of recession is less than $0.1 \mathrm{log}$ cycle per day. $N$ is the approximate duration of surface runoff from Linsley and others (1982):

$$
N=(A)^{0.2}
$$

where

$$
\begin{aligned}
& N \quad \text { the time after which surface runoff ceases, } \\
& \text { in days; and } \\
& A \quad \text { is the watershed area, in square miles. }
\end{aligned}
$$

\section{HYSEP}

HYSEP (Sloto and Crouse, 1996) automates three methods - the fixed interval, sliding interval, and local minimum - originally developed by Pettyjohn and Henning (1979) to separate the components of streamflow. Different algorithms are used to construct the base-flow hydrograph by drawing lines connecting low points of the streamflow hydrograph (fig. 3). Each method uses an interval of $2 N^{*}$ days to search the hydrograph for the minimum streamflow during that interval. Sloto and Crouse (1996) used the symbol "** to denote that the interval used is not exactly equal to twice

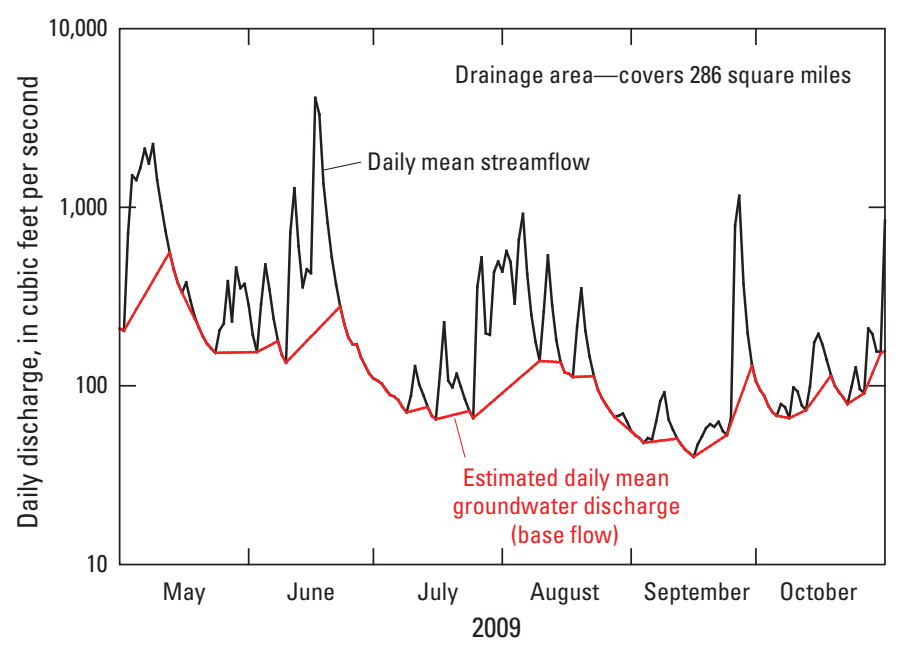

Figure 2. Hydrograph showing the results of streamflow partitioning from PART at streamflow-gaging station 03208500 Russell Fork at Haysi, Virginia. Groundwater discharge (base flow) equals streamflow where the curves coincide. The requirement for antecedent recession is 3 days. the value of $N$, but instead, is the nearest odd integer between 3 and 11 to $2 N$.

The fixed-interval method determines the lowest streamflow discharge in the interval $2 N^{*}$ and assigns that discharge to all days in the interval. This process starts with the first day of streamflow record, then the analysis is moved forward $2 N^{*}$ days and the process is repeated. The base-flow hydrograph is constructed by simply connecting the assigned values for each interval (fig. 3A). The sliding-interval method determines the lowest streamflow discharge for the interval $0.5\left(2 N^{*}-1\right)$ days centered on the day of interest and then assigns that discharge to the median day of the interval. The interval is shifted forward to the next day and the process is repeated. The daily discharge values are then connected to construct the base-flow hydrograph (fig. 3B). The local-minimum method determines whether the daily streamflow discharge is the lowest for the interval $0.5\left(2 N^{*}-1\right)$ and if it is, then it is considered to be the local minimum and is connected by straight lines to adjacent local minimums (fig. 3C).

$\mathrm{BFI}$

The BFI program (Wahl and Wahl, 1988) consists of two methods - standard and modified — and follows a set of procedures originally proposed by the British Institute of Hydrology (Institute of Hydrology, 1980a, b) in which the streamflow record is partitioned into intervals $N$-days in length (fig. 4). During each $N$-day interval, the minimum streamflow is identified and compared to adjacent minimums. If a given minimum is less than the turning-point test factor, $f$, then that minimum is designated as a turning point. These turning points are then connected to construct the base-flow hydrograph. For the BFI-standard method, the default values for $N$ and $f$ of 5 days and 90 percent, respectively, were used at all gages. In the BFI-modified method, the parameter $f$ is replaced by a daily recession index, $K^{\prime}$, defined as of length

$$
K^{\prime}=f^{\left(\frac{1}{N}\right)}
$$

which equals 0.979 based on the default values used for parameters $N$ and $f$ in the BFI-standard method.

\section{PRISM Precipitation}

Annual grids of precipitation from 1900 to 2011 interpolated from the parameter-elevation regressions on independent slopes model (PRISM) were downloaded from the PRISM Climate Group Web site (PRISM Climate Group, 2014). PRISM is an analytical model that generates gridded estimates of annual precipitation from point data at National Weather Service climatological stations and a digital elevation model (DEM) (Di Luzio and others, 2008). Annual precipitation values for each streamflow gage were determined by calculating the average of cell values within the basin boundaries as defined in the GAGES-II dataset (Falcone, 2011). 


\section{A. Fixed interval}

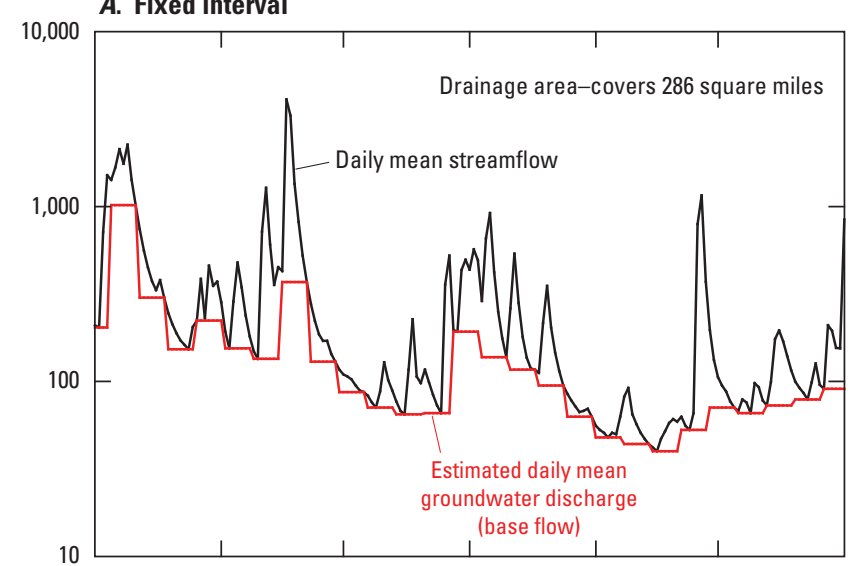

B. Sliding interval

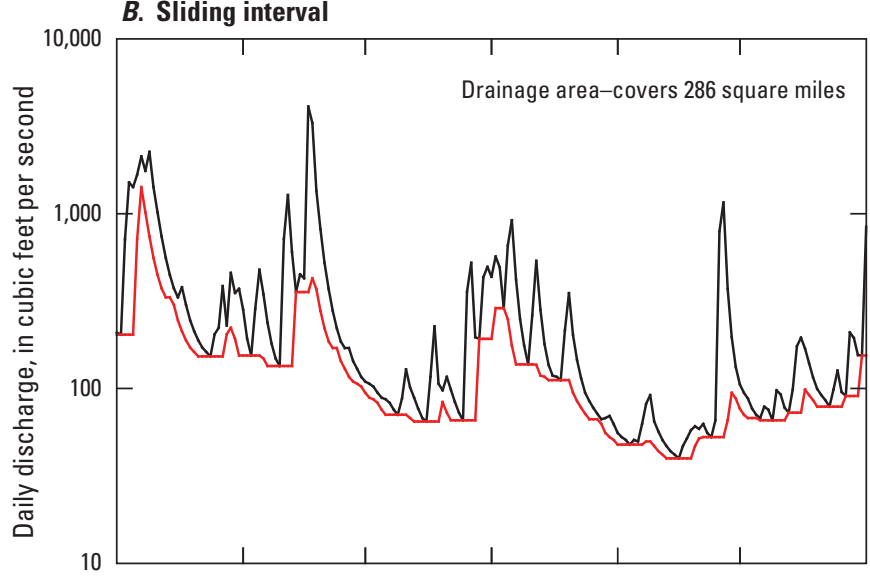

C. Local minimum

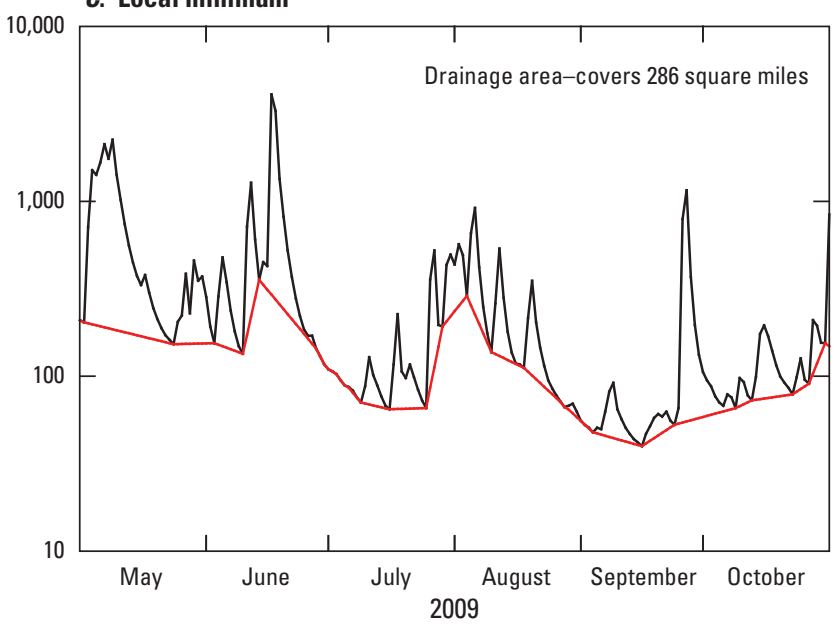

Figure 3. Hydrographs showing the results from the HYSEP program $-A$, the fixed interval; $B$, sliding interval; and $C$, local minimum methods - at streamflow-gaging station 03208500 Russell Fork at Haysi, Virginia.

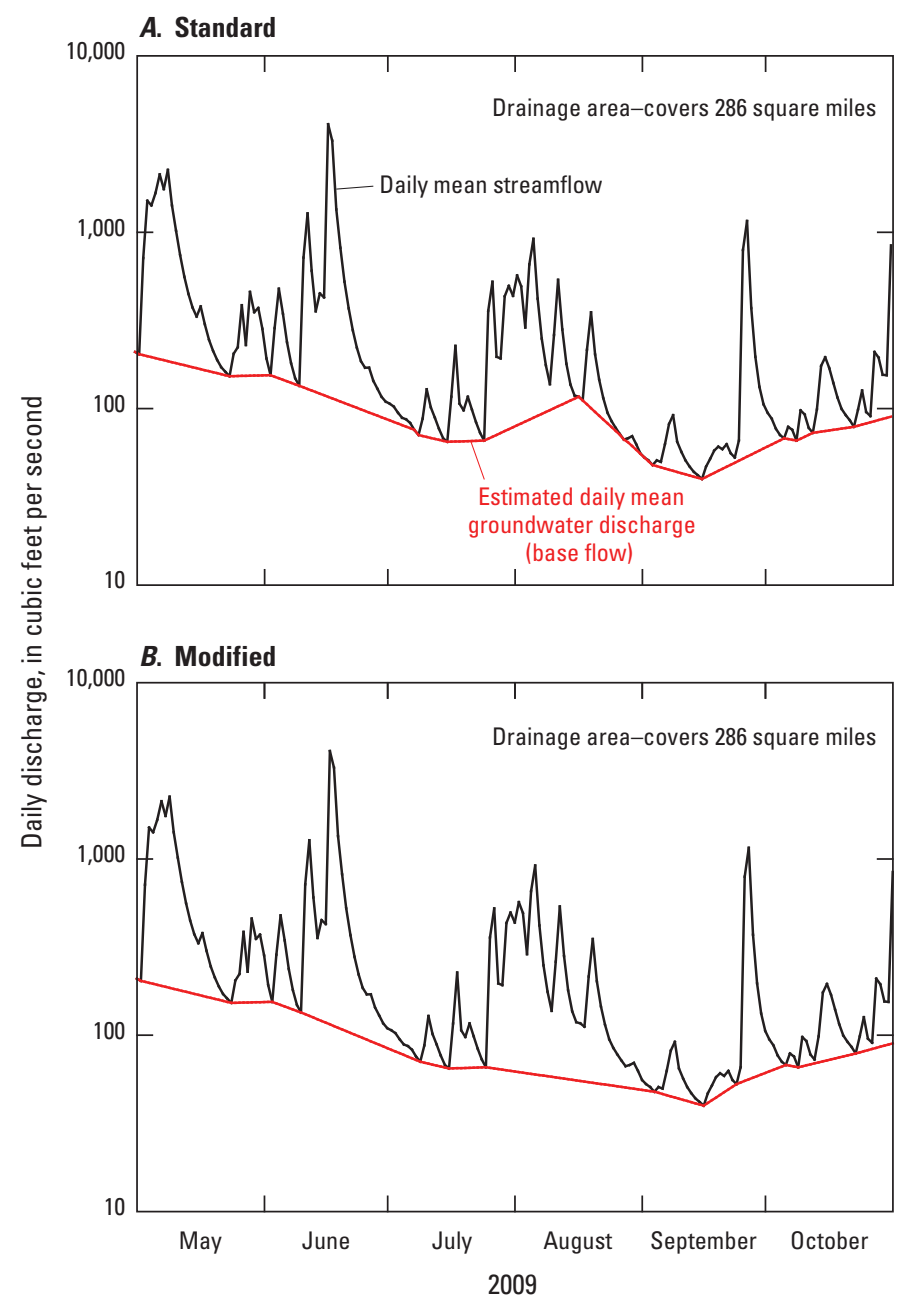

Figure 4. Hydrographs showing the results from the BFI program- $A$, the standard; and $B$, modified approachesat streamflow-gaging station 03208500 Russell Fork at Haysi, Virginia. 


\section{Annual and Average Estimates of Water-Budget Components}

Three appendixes are included as Microsoft Excel files that present a list of site and locational information for the 849 streamflow-gaging stations within the Appalachian Plateaus region for which hydrograph separation was conducted (appendix 1), annual estimates of water-budget components quantified using each technique (appendix 2), and average values of water-budget components for the respective period of analysis for each gage (appendix 3). The three separation techniques provide a set of six estimates of base flow, runoff, and BFI for each year of complete record. The dataset contains a total of 20,990 annual water-budget estimates (appendix 2). Annual estimates of runoff were calculated by subtracting the annual base-flow estimates from annual streamflow. Annual estimates of ET were calculated as the difference between annual precipitation and annual streamflow.

All of the hydrograph separation methods have a number of simplifying assumptions that should be considered when using the estimates of base flow presented herein. Barlow and others (2015) provide a list of these assumptions:

1. The streamflow hydrographs reflect contributions from two sources: surface runoff in response to a precipitation event and groundwater discharge from a single aquifer.

2. Diffuse areal groundwater recharge that is uniformly distributed over a watershed predominates rather than focused groundwater recharge, such as from losing stream reaches.

3. All groundwater recharge within the basin discharges to the receiving stream network except the amount evapotranspired directly from the groundwater system (sometimes referred to as riparian evapotranspiration).

4. Groundwater discharge to streams is a continuous process (Healy, 2010).

5. Surface-water and groundwater drainage areas to the streamflow-gaging station coincide.

6. Groundwater is not lost to underlying regional groundwater-flow systems or to groundwater withdrawals.

7. Streams are unregulated and not influenced by reservoirs, streamflow diversions, or wastewater return flows.
Another factor that needs to be considered when using the base-flow estimates is the size of the drainage area. Variability of the base-flow estimates increases as the drainage area decreases (fig. 5). Annual variations in the amount and spatial distribution of precipitation can affect the amount of recharge in basins of limited area (generally less than $10 \mathrm{mi}^{2}$ ), which usually are located in the headwaters sections of watersheds.

\section{Geospatial Data}

The geospatial data provided in appendixes 1-3 are also contained in a personal geodatabase (HydrographSeparation PMAS_DS555.mdb) that can be downloaded from the USGS Water Resources NSDI Node at http://water.usgs.gov/GIS/ dsdl/HydrographSeparation_PMAS_DS944_mdb.zip.

The personal geodatabase contains (1) a point feature class of 849 continuous-record streamflow-gaging stations in the Appalachian Plateaus Region where water-budget components were estimated (PMAS_SW_Sites_pt), (2) a table of annual estimates of water-budget components from 1900 to 2011 (PMAS_Annual_WaterBudget), and (3) a table of average estimates for the respective periods of analysis at each gage (PMAS_Average_WaterBudget). The following waterbudget components are included in the annual and average tables: precipitation, evapotranspiration, streamflow, and six estimates of base flow, runoff, and base-flow index from the separation techniques. Two relationship classes between the USGS station identification number (STAID) attribute in the point feature class and the annual (SitesToAnnualData) and average (SitesToAverageData) tables are included. Digital geospatial metadata compliant with Federal Geographic Data Committee (FGDC) Content Standard for Digital Geospatial Metadata, version FGDC-STD-001-1998 (Federal Geographic Data Committee, 1998), that describe the content of HydrographSeparation_PMAS_DS555.mdb are included with the zip file. 


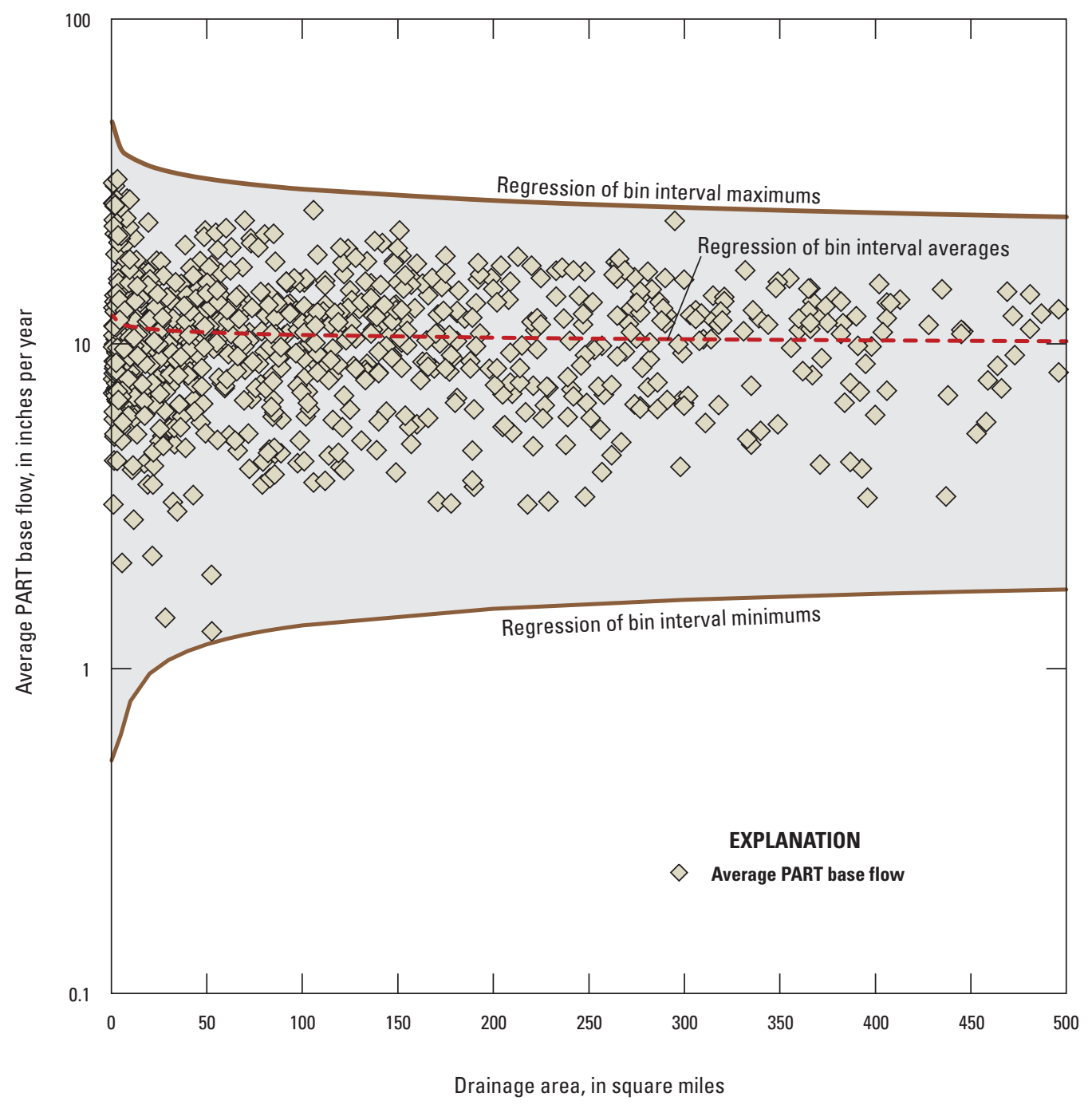

Figure 5. Relation between average base-flow values estimated from the PART method and drainage area of streamflow-gaging stations in the Appalachian Plateaus region. 


\section{References Cited}

Arnold, J.G., Allen, P.M., Muttiah, R., and Bernhardt, G., 1995, Automated base flow separation and recession analysis techniques: Ground Water, v. 33, no. 6, p. 1010-1018.

Barlow, P.M., Cunningham, W.L., Zhai, Tong, and Gray, Mark, 2015, U.S. Geological Survey Groundwater Toolbox, a graphical and mapping interface for analysis of hydrologic data (version 1.0) - User guide for estimation of base flow, runoff, and groundwater recharge from streamflow data: U.S. Geological Survey Techniques and Methods, book 3, chap. B10, 27 p. Also available at http://dx.doi.org/10.3133/ tm3B10.

Daniel, C.C., III, 1996, Ground-water recharge to the regolithfractured crystalline rock aquifer system, Orange County, North Carolina: U.S. Geological Survey Water-Resources Investigations Report 96-4220, 59 p.

Di Luzio, Mauro, Johnson, G.L., Daly, Christopher, Eischeid, J.K., and Arnold, J.G., 2008, Constructing retrospective gridded daily precipitation and temperature datasets for the conterminous United States: Journal of Applied Meteorology and Climatology, v. 47, no. 2, p. 475-497.

Falcone, J.A., 2011, GAGES-II: Geospatial attributes of gages for evaluating streamflow: Accessed October 20, 2011, at http://water.usgs.gov/GIS/metadata/usgswrd/XML/gagesII_ Sept2011.xml.

Federal Geographic Data Committee, 1998, Content standard for digital geospatial metadata: Washington, D.C., Federal Geographic Data Committee, FGDC-STD-001-1998, 78 p. (Revised June 1998.)

Healy, R.W., 2010, Estimating groundwater recharge: Cambridge, United Kingdom, Cambridge University Press, $245 \mathrm{p}$.

Holtschlag, D.J., 1997, A generalized estimate of ground-water recharge rates in the Lower Peninsula of Michigan: U.S. Geological Survey Water-Supply Paper 2437, 37 p. Also available at http://pubs.er.usgs.gov/publication/wsp2437.

Institute of Hydrology, 1980a, Research report, v. 1 of low flow studies: Wallingford, United Kingdom, Institute of Hydrology, $42 \mathrm{p}$.

Institute of Hydrology, 1980b, Catchment characteristic estimation manual, v. 3 of low flow studies: Wallingford, United Kingdom, Institute of Hydrology, 27 p.

Lins, H.F., 2012, USGS Hydro-Climatic Data Network 2009 (HCDN-2009): U.S. Geological Survey Fact Sheet 20123047, 4 p., accessed July 1, 2014, at http://pubs.usgs.gov/ fs $/ 2012 / 3047 /$.
Linsley, R.K., Kohler, M.A., and Paulhus, J.L., 1982, Hydrology for engineers (3d ed.): New York, McGraw-Hill, 508 p.

Nathan, R.J., and McMahon, T.A., 1990, Evaluation of automated techniques for base flow and recession analyses: Water Resources Research, v. 26, no. 7, p. 1465-1473.

Nelms, D.L., Harlow, G.E., Jr., and Hayes, D.C., 1997, Baseflow characteristics of streams in the Valley and Ridge, the Blue Ridge, and the Piedmont Physiographic Provinces of Virginia: U.S. Geological Survey Water-Supply Paper 2457, 48 p. Also available at http://pubs.er.usgs.gov/publication/ wsp2457.

Pettyjohn, W.A., and Henning, Roger, 1979, Preliminary estimate of ground-water recharge rates, related streamflow and water quality in Ohio: Ohio State University Water Resources Center Project Completion Report Number 552, $323 \mathrm{p}$.

PRISM Climate Group, 2014, PRISM climate data: Oregon State University Northwest Alliance for Computational Science and Engineering database, accessed July 7, 2014, at http://www.prismclimate.org. (Data created July 7, 2014.)

Richardson, C.A., 1982, Ground water in the Piedmont Upland of Central Maryland: U.S. Geological Survey Water-Supply Paper 2077, 42 p. Also available at http://pubs.er.usgs.gov/publication/wsp2077.

Risser, D.W., Gburek, W.J., and Folmar, G.J., 2005, Comparison of methods for estimating ground-water recharge and base flow at a small watershed underlain by fractured bedrock in the eastern United States: U.S. Geological Survey Scientific Investigations Report 2005-5038, 31 p. Also available at http://pubs.usgs.gov/sir/2005/5038/.

Rutledge, A.T., 1993, Computer programs for describing the recession of ground-water discharge and for estimating mean ground-water recharge and discharge from streamflow records: U.S. Geological Survey Water-Resources Investigations Report 93-4121, 45 p. Also available at http://pubs.er.usgs.gov/publication/wri934121.

Rutledge, A.T., 1998, Computer programs for describing the recession of ground-water discharge and for estimating mean ground-water recharge and discharge from streamflow data-Update: U.S. Geological Survey Water-Resources Investigations Report 98-4148, 43 p. Also available at http://pubs.er.usgs.gov/publication/wri984148.

Rutledge, A.T., and Mesko, T.O., 1996, Estimated hydrologic characteristics of shallow aquifer systems in the Valley and Ridge, the Blue Ridge, and the Piedmont Physiographic Provinces based on analysis of streamflow recession and base flow: U.S. Geological Survey Professional Paper 1422-B, 58 p. Also available at http://pubs.er.usgs.gov/ publication/pp1422B. 
Sloto, R.A., and Crouse, M.Y., 1996, HYSEP-A computer program for streamflow hydrograph separation and analysis: U.S. Geological Survey Water-Resources Investigations Report 96-4040, 46 p. http://pubs.er.usgs.gov/publication/ wri964040.

Szilagyi, Jozef, Harvey, F.E., and Ayers, J.F., 2003, Regional estimation of base recharge to ground water using water balance and a base-flow index: Ground Water, v. 41, no. 4, p. 504-513.

Trainer, F.W., and Watkins, F.A., Jr., 1975, Geohydrologic reconnaissance of the upper Potomac River Basin: U.S. Geological Survey Water-Supply Paper 2035, 68 p. Also available at http://pubs.er.usgs.gov/publication/wsp2035.
U.S. Geological Survey, 1989, Federal Glossary of selected terms - Subsurface-water flow and solute transport: U.S. Geological Survey, Office of Water Data Coordination, Ground Water Subcommittee of the Federal Interagency Advisory Committee on Water Data, 38 p.

Wahl, K.L., and Wahl, T.L., 1988, BFI—A computer program for determining an index to base flow: U.S. Bureau of Reclamation Water Resources Research Laboratory, accessed June 30, 2014, at http://www.usbr.gov/pmts/ hydraulics_lab/twahl/bfi/. 


\section{Appendixes}

[Microsoft Excel files available for download at http://pubs.usgs.gov/ds/0944/]

Appendix 1. List of streamflow-gaging stations in the Appalachian Plateaus region used to estimate annual water-budget components based on hydrograph separation and PRISM precipitation, 1900-2011.

Appendix 2. Annual estimates of water-budget components based on hydrograph separation and PRISM precipitation for gaged basins in the Appalachian Plateaus region, 1900-2011.

Appendix 3. Average estimates for the period of analysis of water-budget components based on hydrograph separation and PRISM precipitation for gaged basins in the Appalachian Plateaus region, 1900-2011. 
Manuscript approved June 19, 2015

Prepared by the USGS Science Publishing Network Raleigh Publishing Service Center

Edited by Michael Deacon

Illustrations by James E. Banton

Layout by Caryl J. Wipperfurth

For more information concerning this report, contact: Director

U.S. Geological Survey Virginia Water Science Center

1730 East Parham Road

Richmond, VA 23228

http://va.water.usgs.gov/ 
章.

흘

후

옹

? 